\title{
Race and Nation in Ella McFadyen's Pegmen Tales
}

\author{
Raza y nación en Pegmen Tales de Ella McFadyen \\ Raça i nació en Pegmen Tales d'Ella McFadyen
}

\author{
Christopher Kelen. Emeritus Professor, University of Macau. Conjoint Professor, \\ University of Newcastle. kitkelen@gmail.com
}

\begin{abstract}
In Ella McFadyen's 1940's Pegmen Tales the reader witnesses an Australian wishfulness read in the triumphant adventures of the small - of domestic objects brought to life through the imagination of children. In McFadyen's highly didactic tales, clothes pegs stolen and deliberately misused come to embody an understated national ethos with biblical pretensions. The Peg family sail the world in their "Ark", spreading antipodean wonder, cheer and ingenuity everywhere they go. The Pegs themselves - as home-made toys - represent the imaginative ingenuity of Australian children. These are toys any child could make, and so may be read as a social leveller. The dream bringing them to life is that of decent, healthy children and the Pegs (as post-war family, sans father, strive to set themselves and the world good standards).

Every anthropomorphism is deservedly read as comment on the human race or some department or aspect of it, and in this case it is Australian class, race and national pretensions which are promoted through the vehicle of mainly exemplary characters who, in their travels - for the sake of plot negotiate a series of mildly ethical crises, and always come out smiling.

This paper proceeds by considering the issues raised above in relation a small number of episodes from the tales: these dealing with the invasion of rogue mice, the creation of the Pegmen, with Pongo (from the Congo) and the Australian Aborigines, with the Peg's expedition to Antarctica and with the metamorphosis of swagmen into grey kangaroos.

Keywords: Ella McFadyen, race, nation, colonialism.

\section{Resum}

En l'obra de 1940, Pegmen Tales, d'Ella McFadyen el lector és testimoni d'un miratge australià a les aventures triomfants d'allò menut - d'objectes domèstics que cobren vida a través de la imaginació dels infants. Als contes, altament didàctics, de McFadyen les pinces de la roba furtades i deliberadament maltractades prenen cos i declaren un ethos nacional amb pretensions bíbliques. La família Pinça navega pel mon al seu "Ark", tot propagant un pensament antípoda, alegre i ingenu allà on van. Les Pinces mateixes - com a joguets fets a casa - representen la ingenuïtat imaginativa dels infants australians. Aquests són joguets que qualsevol infant pot construir, i així pot ser llegit com un anivellador social. El somni de fer-los cobrar vida pertany als decents i sans xiquets i les Pinces (com a famílies de postguerra sense pare, que pugnen per adequar-se als bons estàndards mundials).
\end{abstract}


Tot antropomorfisme és merescudament llegit com un comentari de la raça humana o alguna secció o aspecte seu, i en aquest cas són les pretensions nacionals, de classe i raça les que són promogudes a través del vehicle, principalment, de personatges exemplars que, als seus viatges - necessaris per a la trama - gestionen una sèrie de crisis suaument ètiques, de les quals sempre se n'ixen somrient.

Aquest article es desenvolupa tot considerant els aspectes contemplats adés en relació a un curt nombre d'episodis d'aquests contes: els que tenen a veure amb la invasió dels ratolins renegats, la creació dels Pegmen (homes-pinça), amb Pongo (del Congo) i els aborígens australians, amb l'expedició de les Pinces a la Antàrtida i amb la metamorfosi dels homes fanfarrons en cangurs grisos.

Paraules clau: Ella McFadyen, raça, nació, colonialisme.

\section{Resumen}

En la obra de 1940, Pegmen Tales, de Ella McFadyen el lector es testigo de un espejismo australiano en las aventuras triunfales de lo pequeño - de objetos domésticos que cobran vida a través de la imaginación de los niños y niñas. En los cuentos, altamente didácticos, de McFadyen las pinzas de la ropa robadas y deliberadamente maltratadas, toman cuerpo y declaran un ethos nacional con pretensiones bíblicas. La familia Pinza navega por el mundo en su "Ark" propagando un pensamiento antípoda, alegre e ingenuo allá donde van. Las Pinzas mismas - como juguetes hechos en casa representan la ingenuidad imaginativa de la infancia australiana. Estos son juguetes que cualquier niño o niña puede construir, y así puede ser leído como un nivelador social. El sueño de hacerles cobrar vida pertenece a los decentes y sanos niños y las Pinzas (como familias de posguerra sin padre que pugnan por adecuarse a los buenos estándares mundiales).

Todo antropomorfismo es merecidamente leído como un comentario de la raza humana o alguna sección o aspecto suyo, en este caso son las pretensiones nacionales de clase y raza las que se promueven a través del vehículo, principalmente, de personajes ejemplares que, en sus viajes necesarios para la trama - gestionan una serie de crisis suavemente éticas, de las que siempre salen sonrientes.

Este artículo procede considerando los aspectos contemplados anteriormente en relación a un pequeño número de episodios de estos cuentos: los relacionados con la invasión de los ratones renegados, la creación de los Pegmen (hombres-pinza), con Pongo (del Congo) y los aborígenes australianos, con la expedición de las Pinzas a la Antártida y con la metamorfosis de los hombres fanfarrones en canguros grises.

Paraules clau: Ella McFadyen, raza, nación, colonialismo.

\section{Race and Nation in Ella McFadyen's Pegmen Tales}

Ella McFadyeni was, from the 1940's through to the 1970's, a writer of extraordinary popularity among Australian children. McFadyen was most famous for her Pegmen series of stories, penned in the forties and fifties, enjoying exposure, first in The Courier Mail in Brisbane, then in book form and on ABC radio. The 'pegmen' (and women) are a family, created through the imagination of children out of those everyday items with which washing is hung on the clothes 
line. Brought to life to save themselves from a flooding river, their adventures take them seafaring to far corners of the world.

Motive for this article is the fact that four decades and more after her death, McFadyen has been largely forgotten, and, despite the obvious quality of her imagination and writing, is not the subject of contemporary scholarly interest. McFadyen's work is however interestingly representative of the Australian psyche of the 40's and 50 's, and of attitudes to childhood in Australia, as they were evolving at that time.

Commencing in 1946, The Pegmen phenomenon (comparable with and contemporaneous with $\mathrm{Al}$ Capp's Shmoo in the United States) represents an immediate post-war artefact and, as such, reflects the Motive for this article is the fact that four decades and more after her death, McFadyen has been largely forgotten, and, despite the obvious quality of her imagination and writing, is not the subject of contemporary scholarly interest. McFadyen's work is however interestingly representative of the

Australian psyche of the 40's and 50's, and of attitudes to childhood in Australia, as they were evolving at that time. racism and fears and hopes of the time. Frequently evident in the text is the condescension of a now threatened imperial and colonial mindset, for dark skinned foreigners and for Aboriginals alike. And yet, along with the undeniable racism, there is deep respect and sympathy for autochonous Australia, its people, its fauna and flora.

Ella McFadyen was a tough old Sydneysider. The walking club she patronized, 'The Boomerang Walking Club', insisted its young members be able to walk twenty miles through the bush in a day and get home under their own steam. It was by means of such tough love, inside and outside of her storyworld, McFadyen engendered a deep affection for the bush and for Australia, perhaps consonant with the efforts of her contemporary Jindyworabak poets. McFadyen claimed a heaven without gumtrees was unimaginable. A fierce early defender of Australian culture from American influences (and Disneyfication in particular), McFadyen undeniably deserves recognition for her efforts in developing and dignifying an Australian literature children could love. 
In Ella McFadyen's 1940's Pegmen Tales the reader witnesses an Australian wishfulness read in the triumphant adventures of the small - of domestic objects brought to life through the imagination of children. In these highly didactic tales, clothes pegs stolen and deliberately

In Ella McFadyen's 1940's Pegmen Tales the reader witnesses an Australian wishfulness read in the triumphant adventures of the small - of domestic objects brought to life through the imagination of children misused come to embody an understated national ethos with biblical pretensions. The Peg family sail the world in their "Ark", spreading antipodean wonder, cheer and ingenuity everywhere they go. The Pegs themselves - as home-made toys - represent the imaginative ingenuity of Australian children. These are toys any child could make, and so may be read as a social leveller. The dream bringing them to life is that of decent, healthy children and the Pegs

(as post-war family, sans father, strive to set themselves and the world good standards).

Every anthropomorphism is deservedly read as comment on the human race or some department or aspect of it, and in this case it is Australian class, race and national pretensions which are promoted through the vehicle of mainly exemplary characters who, in their travels for the sake of plot - negotiate a series of mildly ethical crises, and always come out smiling.

This paper proceeds by considering the issues raised above in relation a small number of episodes from the tales: these dealing with the invasion of rogue mice, the creation of the Pegmen, with Pongo (from the Congo) and the Australian Aborigines, with the Peg's expedition to Antarctica and with the metamorphosis of swagmen into grey kangaroos.

\section{Rogue mice at Wanderoo}

Fear of foreign invasion loomed large in the minds of post-war Australians. The specific Japanese threat of the Pacific war was succeeded by vaguer cold war concerns (as per the "domino effect"), heightened in Australia's case with the collapse of the British Empire in the east. These developments need to be read against a more general and long-term fear of the "yellow peril". The racially motivated "white Australia" immigration policy (instituted at the time of Federation in 1901, of the Australian colonies (1901), through the "Immigration Restriction Act", is one that will enjoy bipartisan political support well into the sixties. The specific purpose of that policy was to exclude potential Asian migrants. So there will be, at the time of writing, a receptive audience for the idea of foreign evils and the need to defend against them.

In the chapter "Night at Wanderoo" we see the decadence of rodents presented as the archetypal characters expecting a free lunch. In the "Mouse Polka": 
My mother said

When I was born:

"Go and frisk

In the farmer's corn.

Farmers labour

The livelong day

So jolly young mice

Can eat and play."

"Frolic and frisk,

And lift your feet,

And then let's sup

On the farmer's wheat."

(p.167)

It is in the context of such dangerous attitudes the narrator is able to confide in us that: "I don't hold with those mouse cartoons; they only encourage the mice, and they're a sight too cheeky without encouragement" (169). Early days for Disney, it is interesting to note that at this time the idea of a cartoon mouse protagonist was able to be challenged as inappropriate, as providing a poor role model in terms of responsible citizenship.

In the depiction of the mice at Wanderoo Station, we see class distinction anthropomorphized in a way that might be characteristic of the description of a like distinction in another culture (for instance in Chinese or in Malay culture). The mice in the piece are the inhabitants of the ticket-selling window in the station-master's office at Wanderoo siding. They live in the pigeon holes for the tickets and have conveniently sorted themselves into classes as per ticket classifications: "Up among the first class tickets lived mice who seemed to be of a more refined type" (170). The "seemed to be" is here suggestive of the opacity of customs of another culture. The mice lower down are of a more homely sort:

...in the much-used pigeon holes, where the edges were rather grimy because so many second-class tickets were needed that the woodwork got rubbed with reaching for them in a hurry - these mice, I say, were of a coarser sort. In one of them a mouse was sitting in his shirt sleeves, a pipe in his mouth, and his feet up on the table. Next door to him a mother mouse was busy with a tub, washing out small mouse-garments of a very doubtful colour and hanging them to dry on a sagging string line. The name of this pigeon hole was "Nibbler's Rest". A place near it had the simple name of "The'Ole". (p.170) 
The empathy expressed for the underdog here is somewhat undermined in the following paragraph by the station-master's candid admission that the mice are "bringing down the tone. Getting the station a bad name" (p.170). Tabkin, the station-master's female cat is clearly not up to the job of mouse management. However the Peg family have brought with them a readymade solution in the form of Blackie - a cat disappointed in love - whom the Pegs have picked up in their travels and who has already shown his mettle in dispersing the polka-dancing rodents just met. Tabkin is already impressed with this vigorous feline and Blackie adds matrimonial hopes to vocational interests when he takes Tabkin's paw in hand and offers humbly to share with her the quarters he has just been offered: "Maybe if I'm a lucky cat, it will very soon be your house, so if you don't mind, please, station-master, I think you might make it big enough for two" (p.173).

The gender roles are interesting here in terms of the marital decision-making process. Tabkin is a little shy, so Blackie eases the way for the forthcoming nuptials with: "She doesn't have to say if she likes me; she'd let me know soon enough if she didn't" (p.173). This sentimental business is however soon interrupted by the arrival of an unscheduled mouse train with which Blackie and the Pegs and the station-master must immediately deal. The narrator unites with them against the foreign menace, and we now see evaporated any empathy there had been for these inferior and threatening others. These mice are not the cheerful coolies and restauranteurs of Dixon Street (in Sydney's Chinatown) - this is your definitive dangerous foreign hoard. Here's how they appear to the station-master:

It wasn't the strangeness of the gaily coloured engine and trucks, nor of the guard's van, picked out in blue and yellow at the rear, although these were unfamiliar to the station-master, who knew all the trains that passed through regularly as well as he knew the buttons on his coat. What caused him to stare with a gaze of fixed horror was that out of the cab of the engine, and out of the first truck, and out of the guard's van at the end, looked a crowd of faces. They were evil faces, each one wearing a scowl - the faces of the biggest, boldest, most desperate-looking mice that you ever saw in your worst dreams. (p.174)

And of course the station-master knows instinctively what it is that they're up to - he knows that their plan is to seize the station and steal the tickets, to rob the cash, blow up the safe, "raid the siding and carry off the wheat" (p.174).

How can the marauders be stopped? 
The point is made that these reckless invaders know no decorum - whereas "all respectable drivers of trains know that they simply must pull up if the signals are set against them... those reckless mice took no more notice of the signals than if they had not existed" (p.174). The result is that soon "the whole length of the train was a parade of enormously overgrown mouse faces, staring and glaring at the dauntless three on the platform" (p.174).

How do the local mice respond to this apparently foreign threat from mice so clearly of a different stripe? "Resident mice from all parts of the goods yard began to gather and offer encouraging squeaks and advice to the raiders" (p.175). Fifth column dangers are real enough and it is clear that with the local mice the allegorical bond of race outweighs anything resembling a patriotic feeling for place. Leadership is called for in such circumstances, or - as the narrator tells us - "it was one of those desperate moments when someone simply has to think quickly and act firmly or all is lost" (175).

Blackie is just the cat for that job and victory over the rogue mice comes when Blackie and the station-master combine their efforts with fire extinguishers to - among other things - blind the driver so that the mouse train plummets off a bridge to a watery grave in the deep gully below, with this poetic conclusion: "Only bubbles floated upwards in the moonlight, like showers of blown thistledown" (175).

The conflation of rodent fears with the fear of foreign others presents as a convincing narrative strategy for an Australian readership of the forties. Each of these phobias would have been credible and heartfelt, less than half a century since the last outbreak of plague in Sydney and only a few years after the Japanese bombing of Darwin. The chapter ends with the wheat saved and a beautiful instance of the framing on which the whole of the allegory depends. Adventure over, Nobby Peg thinks fondly of his bunk on the ark.

Wish I were in bed now," he thought wearily, his fingers closing over the queerly marked stone in his pocket. And he was.

He was wide awake but lying snugly tucked up in his bunk, wondering how much of the night's adventures had really happened, or how much of them he had dreamed. (p.176) 
One of my aims in this paper is to locate in the text a sense of the Australian - of what "Australian-ness" might mean, by surveying a series of attributes or associations, each applying to the Australian condition. This indirect approach is necessitated by the fact that Australian nationhood is neither promoted nor discussed in the text. Symbolic of this is the fact that the only flag illustrated in the book is the Union Jack.

From "Night at Wanderoo" - or the rogue mouse adventure - we can say that Australian-ness is about maintaining and defending predictable and established order in the face of a barbaric threat "coming down the line" (173), and so a threat from what must be geographically above (i.e. Asia). It

The conflation of rodent fears with the fear of foreign others presents as a convincing narrative strategy for an Australian readership of the forties. Each of these phobias would have been credible and heartfelt, less than half a century since the last outbreak of plague in Sydney and only a few years after the Japanese bombing of Darwin. also entails defending an ordered way of life in the face of fifth column threats, even in the control room. This seems pertinent to the Cold War context of McCarthyism in the United States, and to the home-grown hysteria inspired by newly elected Tory Prime Minister, Robert Menzies. A sense of national emergency was taken to a fever pitch in Menzies' unsuccessful attempt to ban the Communist Party of Australia by referendum in 1951.

\section{Creation}

Aboriginality and eco-consciousness are closely linked themes with occasional prevalence in McFadyen's narratives. I think we can in turn associate these with the Jindyworobakism of the mid-century. The Jindyworobaks were a group of white Australian literati (predominantly poets) who sought to promote indigenous themes in their work, along with a respect for Aboriginal culture, a consciousness of place and of an avowedly Australian literary space. Ecoconsciousness is also closely associated with what one might think of as the poetic strain in McFadyen's scene-setting - wherein the author demonstrates a deep respect for the environment in the sense of lived place.

Black people or "the blacks" of McFadyen's text (and the common parlance of the day) are Australian Aboriginals. The Aborigines are in the peg tales, if not necessarily themselves a source of wisdom, certainly a connection with such a source. At the outset (2) McFadyen's narrator tells us that the Black People tell us that the White Cockatoo is the Maker-of-Dreams. Now this is an important function in terms of the narrative structure the author is building. Her story is of a kind of dreamtime and certainly the biblical pretension of the work (or the mock biblical 
business) is established early on, in the form of a creation myth for the pegmen - aka the Peg family - and in the fact of their having an ark to sail on to save themselves from the Flood, immediately following their creation.

Like the Hebrew subjects of the Old Testament, the pegs themselves are equipped with reflexive awareness of their position, as befits a race created:

I guess we're only laundry pegs,

With sticks tacked on for arms and legs.

The children made us for their play,

But since they loved us day by day,

Something in me begins to glow -

This is the at-first wooden voice of Dan Pegman, who next exclaims - "(His voice grew all thrilled and lively now.) "I'm coming to life!"“ (p.11). Dan - one notes - is born adult and with a fullblown sense of manly responsibilities. Hearing the roar of the rising flood, he says to his brother, Nobby, "If I had only known in time, I could have built a raft and saved you and mother" (p.11). There is, in the opening chapters of the book, a Genesian-style interface with the Creator/s. The God of the Old Testament created Adam from dust and Eve from rib, and provided Noah with information, but Peter and Joan - the children who drew on the stolen laundry pegs to bring them to life - actually provide those they create with the Ark that will save them from the Flood. The Flood in this case is the Australian bush-style "flash flood", i.e. the sudden rain that may bring disaster (a drowned man who becomes a ghost [p.7]) but that also brings the dry land back to life and makes the intermittent creeks and rivers run. The Ark comes ready-made in the form of a toy Joan can deploy for the purpose.

From the point of view of the created, early fears that their authors might abandon them to cruel fate are only briefly entertained. There is the thought of a false start - the boys (Dan and Nobby) are not prepared to wake their mother with the gloomy revelation that they've been created just to be drowned. Once woken, it's their mother (Mrs Peg) who inspires them with the confidence that, "The children will help. A little boy as brave as Peter and a girl as kind as Joan would never leave us to drown on Pegmen"s Run" (p.12).

It should be remembered that, from the outset, the Pegs have a charmed life, as demonstrated in the book's opening sentences: "The Pegmen must be the luckiest fellows in the world, to have had so many exciting adventures" (p.1). The characters are the chosen pegs. Facing the calamity 
of the Flood, we quickly see that knowing who and how to be goes with being created: "From the first moment that Dan Pegman stepped aboard the Ark he seemed to know all about ships and sailors. It was just as if he had been meant for a sailor from the beginning. One notes that McFadyen's ethical cosmology and creation myth are by no means exclusively Christian. The biblical is mixed with the native mythology and there is a good dose of home-grown animism thrown in, for instance via the talking frog who lets the children know what dolts they were not to have anticipated the Flood of which they had been warned (p.8). The monotheistic touch is delivered (somewhat parodically) via the mysterious character of the White Cockatoo, of whom we are told, "Only the White Cockatoo, who was responsible for making the wonderful dream with which this began, can explain it. And he won't. He just looks wise and says nothing (p.12).

An inscrutable spirit of place is at work here. In fact it is not only the White Cockatoo who knows all, the Flood of the second chapter is foreshadowed in the first by the secret knowledge of the ants and the frogs and the spiders (p.4). One suspects that the White Cockatoo is another name for the Christian God in this piece - or better, it is a means of avoiding any need to bring that kind of character directly into the story. In the syncretic religion here assumed a blind spot of required faith is comfortably furnished by this wise mute bird who won't explain the dream in which the story's dreamt. So this is a creed for literature - for authors - as well as for the land God has written. And so the text in English, intended for the white Australian child, locates in the motif of the dreamtime and in the idea of being dreamt a point of autochthony, beyond which explanation is abandoned.

Beyond the particularity of the syncretism here entailed in reconciling various incompatible systems of belief, one might claim a peculiarly Australian aspect to this creation myth, namely

Beyond the particularity of the syncretism here entailed in reconciling various incompatible systems of belief, one might claim a peculiarly Australian aspect to this creation myth, namely that the pegs are - in Michel De Certeau's terms - a perruque $\neg$ - that is to say these characters are created out of a theft from the everyday. that the pegs are - in Michel De Certeau's terms - a perruque - that is to say these characters are created out of a theft from the everyday. They are the result of Peter's plan to distract Mrs Flannery, the family's washer-woman, so that Joan can sneak in and steal the pegs needed to make the pegmen. All that follows - all the adventures - are the result of deployment of objects other than for the purpose intended. This, one might claim is typical of a colonial (and sometimes postcolonial) undermining of imperial intentions and perhaps allegorical of the Australian (i.e. the white Australian story) - of all the unintended and unofficial adventures of the country that began as a gaol. 
The unofficial aspects of the pegs' story are there from the beginning, as in the cheekiness of Peter's song, the butt of which is Mrs Flannery:

Old Mrs Soapsuds

Came to us to wash,

She heated up the copper

And tumbled in - splosh!

Old Mrs Soapsuds

Was crazy in her head,

She went to hang the washing out

And hung herself instead.

(p.5)

And the unofficial tone continues throughout. Although the temperament of the story is persistently Australia, there is very little of the idea of an Australian national identity in the book. The subjects of the story are merely Britishers of a certain antipodean stripe, but the world is their very British oyster. And the arrangement is a cozy one. It is not merely a straightforward case of official authority being tricked out of its power or possessions. Mrs Flannery is a case in point. She is - credibly enough - complicit with Joan in allowing the boyish theft Peter planned, we might say, as the adventure to enable the creation of the pegs: "There, take those three (pegs) in the basket, deary. Will that do?" she asks Joan (6).

So the created world of Joan and Peter, like the created world of the Pegs is an harmonious one, where the center and the periphery of power accommodate each other with a certain amount of harmless play along the way.

\section{Pongo}

The necessary fly in the ointment is Pongo from the Congo, the Ark's Stowaway, who is introduced (in Chapter 4) as an ugly thief (17) of all things delicious and who, by chapter's end is avowing clearly wicked intentions:

What? Rub and scrub

Aboard this tub,

"Cause Captain says I should

I'm Pongo

From the Congo, 
And I don't ever mean to be good.

Pongo is tried for his crimes, found guilty and sentenced by Dan to be hanged at the yard-arm. This impresses Nobby, who had been hoping "all along for a lively sort of ending" (19). At this point female pragmatism, rather than clemency, intervenes. Pongo cannot be hanged today because it's Mrs Peg's washing day. Pursuing a "recommendation to mercy", Pongo is now encouraged to invent extenuating circumstances, and told that what's intended there is "any sort of yarn that will get you off, even if it's pretty thin" (20). Pongo, we learn at this point - if we choose to believe him - is "not really a stowaway" (20). The prisoner tells them he "was aboard all the time": "I'm the wooden monkey that belongs to the Ark" (20).

As is often the case in creation myths, we see that there are two ways of reading Pongo's situation. Yes, he's from the Congo - this is the kind of place a monkey might rhyme from, and that might make him a stowaway; but in another sense he is indigenous to the Ark itself, perhaps has more rights there than do the Pegs. Accordingly, as a first offender he is allowed to work his passage, as a cabin boy and soon finds himself being patted on the head (20).

Saved from the gallows, Pongo goes on to fill the role of foil throughout the tale as the character who is definitively "not a white man". The book ends with Pongo in much the same straits as in Chapter 4; this time the monkey is a prisoner in the Tower of London, whose lamentations earn him threepennyworth of peanuts from the Yeoman of the Beefeater Guards. Meanwhile Dan is knighted by the king and Mrs Peg made a dame. The final illustration for the book: Pongo's tail flying the Union Jack.

If Pongo is the tale's unique and consistent Caliban, then the Australian Aborigines in the story (especially in the chapter titled "Corroboree") receive very different treatment. They're met in idyllic circumstances and on their own turf: "a place in the river where a pretty creek ran down under tall trees" (105). There Nobby encounters "a couple of black boys about his own age" (104). The children are depicted in the following terms: "merry little boys and girls without many clothes on their dark little bodies, but mops of black hair, and smiles that showed their lovely white teeth" (104). Allegorical of the native's thirst for the true religion (which in this case need not be revealed), we learn that, "these black people had seen the Ark on the river, and they were very much interested, and wanted to know more about the wonderful boat that was so much bigger than the canoes they could build for themselves from bark or hollowed-out logs" (104). Nobby goes fishing with the cheerful youngsters and they appreciate each other's company. When Mrs Peg says to Dan, philanthropically, "I would like to do something for those 
blacks", Dan gives "the line" on the Aboriginal situation: "I know how you feel mother. The white people have taken their land, and we ought to do something to make up for it" (106). When Nobby asks, "Shouldn't the first white people have bought the land from the blacks", Dan has to explain what happened:

\begin{abstract}
"No," said Dan. "You see, Nobby, the blacks did not use money. They got what they needed straight from the bush, where money is no use. But you can help the blacks by giving them useful things, like those fishing-hooks. Some of the first white settlers were fair enough, and gave the blacks food and blankets. But you see, the blacks saw no harm in spearing the white men's cattle when they saw the white men shooting kangaroos, which was their tribe's food. So soon there was trouble, and the white men complained that when they gave the blacks food they made a feast and ate it all, instead of saving some for later on." (p.106-7)
\end{abstract}

Mrs Peg at this point adds that without pantries or ice or refrigerators, the natives would have no way of keeping food, with ants and flies and heat to spoil it. Empathy is there when Mrs Peg admits, "if we had to wander about, building bark huts to camp in, I don't think we could keep house any better than they do. And we shouldn't be half so clever at finding our own food" (107).

The author's empathy is clearly revealed in the "pleasant voices of the blacks" when they reveal a capacity for role reversal, singing in their pidgin English:

Good feller Nobby,

All same brother

Him no matter got

White missus mother.

Him no matter got

White-feller skin;

Budgery black heart,

Inside in.

(p.107)

For which the following gloss is offered: "they meant that, in spite of having been born a white boy, Nobby was every bit as good as a blackfellow, and had just as kind a heart. When you look at it from their point of view, you will see this was the nicest thing they could say about him, just as if we said of a man: 'He's white right through' "(p.107). 
In the corroboree that follows this encounter, there is an impressive cultural exchange, with the Pegs and the blacks joining in each other's dances. Harmony with the natural environment is more than implied, when the frogs and snakes and lizards and flying foxes, likewise all join in (110). The effects of this communion with nature are lasting and in the next chapter we learn that "they all had the time of their lives, and they slept like blue-tongue lizards" (113). Meanwhile Pongo has gone missing. We quickly learn that the wicked and superstitious creature has, for his crimes, had the death-bone pointed at him and so believes he will soon die. To cut a long story short, in the end it's work that saves Pongo from psychological suicide. In an effort to stay awake and thus beat the putative "poison", Pongo scrubs and rubs and hangs all the washing, cleans everyone's shoes - thus proving that every animal in the world has its uses, even a monkey (116). This chapter ends with the egalitarian ethos of the Ark expounded:

Busy day or holiday,

Rising with the lark,

Every day's a jolly day

For us aboard the Ark.

We spend our days in jollity,

We're keen upon equality -

Of course we're strictly fair!

No favour and no snobbery,

But since last night's corroboree

All tiresome, hard odd-jobbery

Is poor old Pongo's share.

In sum, "equality" is at someone's expense. One reads that the blacks are harmless others who keep to their own range and for whom we - the civilized readers of the story - ought to be feel some sense of responsibility. More to be pitied than envied, clearly the blacks are not particularly to be blamed. In the figure of Pongo though we see the more onerous aspect of the white man's burden of empire - the dark thieving miscreant "wog" other whom only work can tame. Converting that character into a talking creature with a tail has great convenience for the imperial doublethink on which white world domination depends. The question of who and what is British is left ambiguously open as the adventures conclude, with that Union Jack waving from Pongo's tail. 
The position of Pongo and the idea of reconciliation as applied to the Australian Aborigines in

In sum, "equality" is at someone's expense. One reads that the blacks are harmless others who keep to their own range and for whom we - the civilized readers of the story - ought to be feel some sense of responsibility. More to be pitied than envied, clearly the blacks are not particularly to be blamed. the story reveal a deep ambivalence on the question of race and autochthony: the natives are of the place and so - while their past ill-treatment is understandable - they deserve better; Pongo's status as foreign miscreant is somewhat undermined by the possibility that he was on the Ark from the beginning. Certainly, he is one of God's creatures. Perhaps we get a clearer picture of the race situation in more neutral territory when the Pegs journey to Canada. There Dan explains to his mother:

The days when Redskins and Palefaces, as they used to call each other, were always fighting and trying to kill each other are done. Now the Indians live on Indian Reserves, lands where the white folk aren't suppose to go without permission. The Indians are quite friendly and only dress up in their feathers and war paint to amuse the tourists, and they sell curios to them, and pass around the Peace Pipe. When an Indian offers to smoke the Peace Pipe with you it means he is quite friendly. (p.159)

A combination of apartheid and trivialisation would appear to be the ideal way of dealing with the Aborigines. In Canada, Nobby makes up a song, as follows:

Pine-woods dark in summer,

Where shadowy Indians go,

Maples red in autumn,

Moose-tracks in the snow,

And a dash of prairie winter,

Forty-five below:

Mighty lakes and rivers,

Snow peaks white as bone -

But your strangest wonders

To the traveller shown,

Are beavers building cities,

With wisdom all their own. 
The note to accompany the song lets us know that forty-five below is a temperature Australians will have difficulty imagining. There are some curious mis/mappings of the indigenous and the autochthonous at work here. Indians are shadowy but beavers are wise. Beavers are the progenitors of cities (the strangest wonders); Indians are presumably off following the moose tracks in the snow. It's interesting to consider how these contrasts sit with those noted in the case of Pongo and the Australian natives.

\section{Expedition to Antarctica}

So - where is Australia and the sense of an Australian nationalism in all of this? Clearly Canadian circumstances are analogous with ours. Canadians are of our family. If their natives are a little different and if their sun shines less brightly this only shows how big and accommodating the British Commonwealth is. As already noted, the nationalism entailed in the adventures is ambiguously British/Australian throughout. However, I would like now to turn to an episode with which to explore the specifically Australian kind of (regional) imperialism practised by the crew of the Ark. In the chapter "Down with Monday Morning", the Peg family use their Ark - in the manner of a "First Fleet" - to help the literally downtrodden pegs of the backyard resettle in Antarctica and begin nation building work there. The First Fleet, of Captain Arthur Philip, brought convicts to Sydney Cove in 1788 , to begin the white settlement there, thus providing the originary myth of white Australia and the date (up to the time of writing) of the official national celebration, "Australia Day" ( $26^{\text {th }}$ January).

The idea of a second Antarctic expedition for the pegs has already been foreshadowed by Nobby's telling Dan that he wishes to revisit the South Pole because he has carelessly left his fountain pen there on their last trip. Of course we soon learn that the seeming omission on Nobby's part is all Pongo's fault, Pongo having "borrowed" the coat it was in at an opportune moment. And now, midnight on Sydney Harbour the Peg family, are ahoy-ed indistinctly by a multitude of pegs just come to life, just finding their voices and afraid of rousing night watchmen or water police. These are the literally downtrodden pegs of the backyard, and after only a little persuasion, Captain Dan will have them all aboard the Ark and help them to resettle in another Great South Land and begin nation building work there. These proletarian pegs are figures sprung from the Depression:

They were pegs - wooden laundry pegs. They were dusty with tramping a long way, and it seemed quite plain they were runaway pegs. They moved stiffly, too, as if not accustomed to using their legs for walking. It must have been hard for them to get so far. Some of them had the suggestion of a face. Others were quite blank-looking, 
without any expression at all. Each one grasped a tiny bundle, and a sort of vague noise ran through their ranks, as though many of them were not yet able to speak, yet all had something they were desperately keen to say. (p.118-119)

When Dan demands that they explain themselves, their lumpen position is made quite clear.

We're just pegs. We've run away. What sort of life does a peg have? Turned out by machinery, sold, bundled up in dozens, into a world where it is always Monday morning. Why, the very men who tend the machines that make us dislike Monday more than any other morning of the week. And it's always Monday for us. A world that smells of steam and soapsuds; a world where women are cross because they have a heavy wash, and no help, and the copper fire is burning badly, and the clothes are a bad colour, and the baby is crying because there is no time to look after it properly. And then, just as the woman has her hands in the tub and the woollens all wet, the telephone rings, and she runs off, wiping her arms on her apron, and comes back more cross than ever because it was someone calling up the wrong number. (p.119)

So we see the chain of alienation in which the prole-pegs are implicated. There is an up-side as well - "a little bit of fun, sitting astride the sheets on windy days and hearing the wet linen under us go flip, flop, wallop!" - but that reverie is short-lived, when the reader is reminded how "holding down sheets on a windy day has been the death of many a good peg" (p.119). Which brings us to a description of how the backyard pegs are literally downtrodden: blown down in the grass, they lie there "getting muddied by worms and prowled over by back-yard cats" (p.119). But still there's a proud sense of whimsy in these characters, one of whom declares something none of the Peg family has yet observed: “...we were once trees. I can just remember a bit about being a tree - a sassafras-tree in a lovely gully. I had starry white flowers all over me, like a wedding veil, in the spring-time, and lyre-birds came and played about my feet" (p.119120).

This sense of having fallen from a state of grace is quickly converted into an accusing question: "Would you like to spend your days in a laundry, with spiders in the roof, after that?" (p.120). Easily persuaded by this compelling rhetoric, it is not long before the prole-pegs are stowed aboard for the Antarctic voyage. The South Pole provides the prole-pegs with the perfect escape from alienation. As Nobby puts it:

No one lives there. You can't wash clothes there, because they would freeze as soon as they were wet. You know we couldn't even wash our faces when we there. That was the one thing about it that Pongo didn't hate. And there really aren't any days of the 
week, down there, because there's only one day and one night in the whole year.

(p.121)

Thus the problem of Monday morning is done away with. And so, in the context of a firmly British self-conception, a modest form of Australian imperialism (and an interesting role reversal/wish fulfilment) is performed when the Peg family help the downtrodden pegs establish their own icy place in the sun, albeit in the extreme antipodes. Referred to as "stowaways" (p.123) and "runaway pegs (p.126) and reminding us variously of convicts, of African slaves, and of refugees smuggled to safety, we learn that, heading out of Sydney Harbour, "there were rows and rows of pegs, all lying as still as sardines in a tin, scarcely daring to breathe until the pilot had gone ashore and the good ship Ark felt the lift of the ocean rollers under the prow" (p.121). At that point we are privileged to hear their song of liberation:

Free, free,

We're putting out to sea.

We feel our manhood stirring,

Though we're packed away below.

Hear us shout our chorus -

All the world's before us.

Ahoy and all that sort of thing,

And yo heave ho!

We soon discover that there was poetry in the peg who could remember being a tree. In a characteristically didactic passage we learn that the prolepegs will have to learn all about evolution in order to understand how to adapt to their new environment. Antarctica is humanly uninhabited but the runaways are welcomed and assisted by friendly penguins, who, for instance, lend spare feathers to help keep them warm. The nation-making ethos is powerfully present in this icy terra nullius where the Peg family do their best to assist the needy underclass they've rescued and to give them a "fair start"

We soon discover that there was poetry in the peg who could remember being a tree. In a characteristically didactic passage we learn that the prole-pegs will have to learn all about evolution in order to understand how to adapt to their new environment. (128). We might read this as the Australian story - i.e. the convict colony story - given a better beginning, even if in more hostile climatic conditions. 
Along the way - via Nobby - we are taught the universal importance of family and belonging: "Just having each other has always seemed to me the most wonderful luck. When I wake up at night sometimes, I think how lonely it must be for other people who don't belong to our family, but are related to perfect strangers and have to go to bed in strange houses." Of course Mrs Peg tells him how silly he is and how "everyone feels that his own home and family is the very centre of the world", and "what a good thing it is that everyone does have that feeling" (129). And so a little empathy is gleaned from the experience of others. We soon see what a good thing these runaway pegs are onto because Antarctica is a great place for mineral exploitation and it turns out to not only be the home of "white coal" but also an effective refrigerator for the ancient vegetables that lie in abundance just below surface of the ice. By virtue of these qualities of the place the nation of "Woodenits" - or so they call themselves - is born. Lumpen and/or proletarian or not, the Woodenits are undoubtedly "white men": they quickly prove themselves possessed of resource, compassion and moral fibre, and may thus be read as models of the colonial type. They are the kind who rise above class disadvantage to make the most of the environment given.

\section{Old swaggies don't die}

Going to sleep in Canada with a medicine-man's magic stone under his pillow, Nobby's noddingoff wish is for a "long bright day in the warm Australian sunshine" (p.161). Sure enough in the next moment he finds himself with "the good sunshine warm on his back, and smelt the dust that rose from his tramping feet, and on either side ran white paddocks of short-strawed, red Australian wheat" (p.161). It's in this idyll Nobby catches up with the swagman ahead of him on the track ("a faded bluey bundled on his shoulders, a clinking black billycan swinging on a strap below it, and a green fly-veil hanging round his shapeless old sun-faded hat" (p.161). The animal identification resurfaces here in the dream, where we're told that Nobby and the swagman "walk along side by side, cheered by each other's companionship, like friendly animals, not trying to think of anything to talk about" (p.161).

The next chapter, "The Wayfarers", reveals both the swaggie's creed and McFadyen's spiritual cosmology for the bush. The swagman scorns the idea that he should ever give up the wallaby track to settle down:

Give up sleeping under the sky, with the trees for friends; give up the smell of the dew and the dawn coming fresh over the hill, and the birds beginning a new day? Give up all this to stay still in one place with a roof over my head and walls to shut me in? Never! (163) 
When the swagman's sung the "Song of the Bounding "Roo" we learn why it won't be necessary for him to give up the track and the life out of doors. That's because old swagmen don't die, they turn into kangaroos. The point is demonstrated the moment it's made by the passage close by our protagonist, and his sundowner friend, of a fine grey kangaroo, who jerks his head sideways to say, "G'day, Joe. How're you going". Joe reveals that this was his old mate, Bob, with whom he tramped for thirty years: "I guess he'll be just around the next bend, hanging about waiting for me. I'Il lie down here and sleep a bit, young fella, and when I wake I'll be a "roo with a fine new pair of feet, and Bob and I will take the

Rhetorically, the impression given here is that of the opposite of an anthropomorphism: What's foregrounded is not the kangaroo taking on the attributes of the human we know as swagman; rather the reader's eyes are on transformation of the free (but troubled) man into the free (unfence-able) animal, that is the symbol of his country. And so the oneiric idyll of the Australian identity - one we need not mention as national - is embodied in the figure of the white man becoming autochthonous through the vehicle of metamorphosis as fauna. track together" (p.165). The song echoes "Waltzing Matilda" (Australia's unofficial national song) from the outset, opening with these lines: "I am waltzing my Matilda/In the bush beyond Manildra,/With my tucker-bag and billy in my pack..." (p.164).

Rhetorically, the impression given here is that of the opposite of an anthropomorphism: What's foregrounded is not the kangaroo taking on the attributes of the human we know as swagman; rather the reader's eyes are on transformation of the free (but troubled) man into the free (unfence-able) animal, that is the symbol of his country. And so the oneiric idyll of the Australian identity - one we need not mention as national - is embodied in the figure of the white man becoming autochthonous through the vehicle of metamorphosis as fauna.

\section{Conclusions}

Thus I hope it is demonstrated that McFadyen's highly didactic tales, offer child and adult reader alike an unpretentious picture of Australia as British nation under construction on its own terms. The national wishfulness of Australians is read both in the triumphant adventures of the domestic and in the imagination of the young. The biblical (or mock biblical) pretensions of the tale give it a mythic authority. Various extra-continental adventures (Canada, Antarctica) go to show how lucky we Australians are (especially in terms of climate). If Pongo reveals to us the dark side of empire's burden then imperial honours bestowed in London show that - despite humble origins - the service to empire of colonials can indeed be acknowledged at the center. 
Settling Antarctica with workless pegs reverses the role in which those yet-to-be Australians found themselves at the time of the First Fleet.

The Pegs - aka Mrs Peg, Nobby and Dan - are paragons of virtue as demonstrated through duty - to empire, to any in distress (even Pongo), to each other, and most of all, of the boys to their mum. In the case of the Antarctic settlement we see that those once downtrodden help those now in this position. Though the point is never laboured, this is a Christian thing to do, just as is rendering assistance to the blacks in Australia. Through covert service to empire, Australians are thus able to aid in the empire's unofficial expansion and so define their sphere of influence. The metamorphosis of swagman into

Thus I hope it is demonstrated that McFadyen's highly didactic tales, offer child and adult reader alike an unpretentious picture of Australia as British nation under construction on its own terms. The national wishfulness of Australians is read both in the triumphant adventures of the domestic and in the imagination of the young. kangaroo completes the mythic cosmology of the cycle of virtuous acts that make Australia a white man's country and provide a lovely bedside yarn. Good night!

\section{References}

McFadyen, E. (1959). The Big Book of Pegmen Tales (containing favourite stories from Pegmen Tales and Pegmen Go Walkabout). Sydney. Angus and Robertson.

How to cite this paper:

Kelen, C. (2019). Race and Nation in Ella McFadyen's Pegmen Tales. Journal of Literary Education, (2), pp. 178-198. doi: 10.7203/JLE.2.13767

\footnotetext{
' Known also as Cinderella, for her nom de plume over decades as Children's Editor for the Sydney Mail.
} 